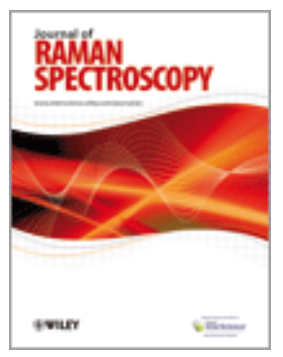

Journal of Raman Spectroscopy

Volume 39 Issue 8, Pages 1050 - 1056

Special Issue: Raman Spectroscopy in Art and Archaeology III

Published Online: 9 May 2008

Copyright (C) 2009 John Wiley \& Sons, Ltd.
(9) Get Sample Copy

- Recommend to Your Librarian

(9) Save journal to My Profile

(9) Set E-Mail Alert

$\nabla$ Email this page

Print this page

RSS web feed (What is RSS?)

Save Article to My Profile Download Citation $\underline{\text { Request Permissions }}$

Previous Abstract $\mid \underline{\text { Next Abstract }}$

Abstract | References | Full Text: $\underline{\text { PDF }}$ (Size: 234K) | Related Articles $\mid$ Citation Tracking

Special Issue: Research Article

\title{
Maya blue-green pigments found in Calakmul, Mexico: a study by Raman and UV- visible spectroscopy
}

Renata Garcia Moreno ${ }^{1}{ }^{*}$, David Strivay ${ }^{1}$, Bernard Gilbert ${ }^{2}$

${ }^{1}$ Centre Européen d'Archéométrie, Université de Liège (CEA-ULg), Sart Tilman, Bât. B5, 4000 Liège, Belgium

${ }^{2}$ Laboratoire de Chimie Analytique, Université de Liège, Sart Tilman, Bât. B6C, 4000, Liège, Belgium

email: Renata Garcia Moreno (Rg.moreno@ulg.ac.be)

*Correspondence to Renata Garcia Moreno, Centre Européen d'Archéométrie, Université de Liège (CEA-ULg), Sart Tilman, Bât. B5, 4000 Liège, Belgium.

\section{KEYWORDS}

Raman and UV-visible spectroscopy • Maya blue • veszelyite $\bullet$ copper pigments $\bullet$ archaeology

\begin{abstract}
After more than two decades of fieldwork in the Maya archaeological site of Calakmul, Mexico, numerous remnants of blue and green pigments have been reported on wall paintings, as well as on funerary paraphernalia, such as masks, miniatures and vases. The importance of these pigments is linked to the sacred values that Maya people associate with blue and green colours since preColumbian times. These hues symbolise water, and are therefore associated with fertility and regeneration. This paper aims to perform a survey of the blue and green pigments used in the Early Classic and Late Classic periods in Calakmul (300-850 A.D.), in order to have a better understanding of their chemical composition and origin. Analyses were performed on microsamples using Raman and UV-visible spectroscopies to evaluate the possibilities that these techniques can offer in future in situ researches on Mesoamerican archaeological materials and objects. With these analyses, we have documented a large blue-green chromatic palette, which includes the earliest Blue Maya and Green Maya known to date, as well as malachite, pseudomalachite and an unknown-up-tonow blue-green mineral pigment, veszelyite, used specifically for ritual objects. The results indicate a careful selection of imported products and the mastering of a complex ancient Maya pictorial tradition. Copyright @ 2008 John Wiley \& Sons, Ltd.
\end{abstract}

Received: 13 November 2007; Accepted: 15 February 2008

\section{DIGITAL OBJECT IDENTIFIER (DOI)}

10.1002/jrs.1972 About DOI

\section{Related Articles}

- Find other articles like this in Wiley InterScience 